\title{
Accelerated Aging Tests for Solar Absorber Coatings
}

\author{
T. C. Diamantino ${ }^{1}$, R. Gonçalves ${ }^{1}$, S. Páscoa ${ }^{1}$, I. Nascimento $^{1}$, T. Chambino ${ }^{1}$, C. Ferreira $^{1}$ and \\ M J. Carvalho ${ }^{1}$ \\ 1 LNEG - Laboratório Nacional de Energia e Geologia. Estrada do Paço do Lumiar, 1649-038 \\ Lisboa, Portugal
}

\begin{abstract}
The need of a higher role of solar energy within the energy mix in the coming decades obliges the systems to increase their performance and reliability. It is demanded that the solar absorbers, as the key component of solar thermal systems, should be low cost with high efficiency for extended lifetimes under different kinds of environments. Commercially, there are two different types of solutions as selective solar absorbers coatings: coatings obtained by physical vapor deposition (PVD) and by paint coatings (PC). These coatings present different physical and chemical characteristics. Therefore, it is important to know how these coatings degrade over time in different environments. Results obtained with two different PVD coatings and three PC, under different accelerated aging tests, are presented. The aging tests performed included different environmental stress corrosion conditions: temperature, humidity, chlorides, sulphur dioxide and nitrogen oxides. Cyclic variation of corrosion promoting gases (sulfur dioxide and nitrogen dioxide), higher humidity, salt spraying and drying seem to be an aging test that reflects the different environments where the solar thermal collectors are exposed. In addition to the contaminants, drying / wetting cycles also play an important role in degradation mechanisms of absorber coatings.
\end{abstract}

Keywords: Aging Tests, Solar Absorbers Coatings

\section{Introduction}

In order to study the durability of selective solar absorber coatings, two alternatives must be considered. One is to study its durability on different natural exposure test sites (Slamova et al. 2016) and, the other, is to develop accelerated aging test procedures in which the stress levels of one or more degradation factors are kept higher relative to in-use conditions (Carlsson et al. 2004 and ISO/TR 16335:2013). The study of the durability of different selective solar absorber coatings in natural exposure was already performed and published by the authors (Diamantino et al. 2017) and is an important knowledge for the optimization of accelerated aging tests to be applied for qualification in terms of durability of the different solar absorber coatings.

Long-term behaviour of selective solar absorbers, used in solar thermal collectors for domestic hot water (DHW) systems, can be performed according to the standard ISO 22975-3:2014. This standard considers three aging tests to guarantee a 25-year service life of selective solar absorbers, which are: 1) assessing thermal stability, 2) determining the resistance to condensed water and 3) resistance to high humidity air containing sulphur dioxide. Evaluation of absorber coatings according to the standard ISO 22975-3:2014 is based on a performance criterion $(P c)$ dependent directly on the optical properties of the collector. In order to an absorber coating to be qualified, the value of $P c$ shall be lower or equal to 0.05 . The qualification of an absorber coating according to the standard ISO 22975-3:2014 takes a minimum of 600 hours for each test and it is very demanding in laboratory equipment to perform all the test sequences. Besides it does not include all major contaminants to which these selective coatings are subjected (Carvalho et al. 2017, Diamantino et al. 2016 and 2017).

In this work, based on results obtained from natural exposure and from the climatic conditions inside collectors, a screening of accelerated aging tests with two PVD coatings and three PC was performed considering different environmental stress corrosion conditions. The objectives are to know the optical behaviour (solar absorptance, thermal emittance, performance criterion function and figure of merit) and the corrosion protection of the different coatings and to propose alternative aging tests for qualification in terms of durability of the different solar absorber coatings. 


\section{Methodology}

\subsection{Selective solar absorber coatings}

In this study, five selective absorber coatings applied on aluminum were considered, two coatings obtained by PVD are commercially available and were acquired from STC manufacturers (PVD 1 - commercial name mirotherm ${ }^{\circledR}$ and PVD 2 - commercial name eta plus ${ }^{\circledR}$ ); three selective paint coatings (two PCs thickness sensitive spectrally selective (TSSS) with silicone binders (PC1 and PC2) which commercial names are SUNCOLOR TS S Black and SOLKOTE HI/SORB-II ${ }^{\text {TM}}$, respectively. PC3 is a thickness insensitive spectrally selective (TISS) type paint coating (commercial name: SUNCOLOR PUR Black). Details of the surface preparation and paints application were already described (Diamantino et al. 2017). The evaluated samples have a dimension of $65 \times 65$ $\mathrm{mm}$ and $65 \times 140 \mathrm{~mm}$. Sample dimension selection depends on the test chambers dimensions.

\subsection{Optical properties}

All the selective solar absorber samples used specifically in this study were optically characterized by measurement of solar absorption $\left(\alpha_{s}\right)$ and thermal emittance $\left(\varepsilon_{t}\right)$. The solar absorption $\left(\alpha_{s}\right)$ was determined based on the reference solar spectral irradiance (incident on a $37^{\circ}$ tilted plane, equator-facing) and the reflectance measurements performed on Perkin Elmer's Spectrophotometer Lambda 950 UV/VIS/NIR with a $150 \mathrm{~mm}$ integrating sphere. The thermal emittance $\left(\varepsilon_{t}\right)$ was determined using a Spectrophotometer Frontier IR/NIR of Perkin Elmer with integrating sphere. A diffuse gold coating reference, calibrated by Avian Technologies LLC, was used for the spectral reflectance measurement between 2.5 and $20 \mu \mathrm{m}$.

Two parameters were used to evaluate the optical behaviour of the materials: 1) performance criterion ( $P c$ ) (according to ISO 22975-3:2014) and 2) figure of merit (FM) (Roberts, D. E. 2013).

1) $P C=-\Delta \alpha_{s}+0.5 \Delta \varepsilon_{t}$

Where $\Delta \alpha_{\mathrm{s}}$ is the change of solar absorptance during an aging test and $\Delta \varepsilon_{\mathrm{t}}$ the change in thermal emittance in the same test. According to ISO 22975-3 absorber coating is qualified if the value of $P_{c}$ is lower or equal to 0.05 .

2) $F M=\alpha_{s}-0.44 \varepsilon_{t}$

Roberts, D. E. (2013) introduces a figure of merit (FM) based on these optical properties with the purpose of evaluating the performance of solar absorber coatings, the larger the value of $F M$ the better the performance.

\subsection{Accelerated aging tests}

Table 1 resumes the parameters of all the accelerated aging tests. The aging test according to the standard ISO 21207:2015 with the code NSS + SO2 + NO2 + DW was performed with three different preconditions (samples without thermal preconditioning, $5 \mathrm{~h}$ and $18 \mathrm{~h}$ of thermal conditioning) to evaluate the influence of temperature $\left(193^{\circ} \mathrm{C}\right)$ in the behaviour of solar absorber coatings to this corrosive environment. NSS+DW and SO2+NO2+DW aging tests were performed with 5 hours of pre thermal conditioning.

The thermal conditioning of the different solar absorber coatings was performed at $193^{\circ} \mathrm{C}$, because it was the higher absorber temperature obtained according to the standard ISO 22975-3:2014 for the coatings considered. The equipment used for thermal conditioning was Heratherm Oven OMH100. The codes assigned to these aging tests are: NSS + SO2 + NO2 + DW, 5h NSS + SO2 + NO2 + DW and 18h NSS + SO2 + NO2 + DW (Table 1).

The NSS and SO2 are aging tests with continuous exposure of contaminants and the remaining tests involve cyclical conditions with different combination of corrosion promoting gases (SO2 and NO2), relative humidity, neutral salt spray and drying, with and without previous thermal conditioning of samples.

\subsection{Corrosivity of accelerated aging tests performed according to ISO standards}

The corrosivity of the accelerated aging tests performed according to ISO standards were obtained based on corrosion rate measurement of standard specimens (carbon steel, zinc, copper and aluminum). The standard 
specimens were acquired, cut, prepared and exposed according to the standard ISO 9226:2012. After exposure to aging tests (NSS, $\mathrm{SO}_{2}$, NSS + TDW, NSS $+\mathrm{SO}_{2}+\mathrm{NO}_{2}+\mathrm{DW}$ ) during 7 days, corrosion products of each metal were removed in accordance with the standard ISO 8407:2009.

Tab. 1: Details of the accelerated aging tests

\begin{tabular}{|c|c|c|c|c|}
\hline $\begin{array}{l}\text { Test type } \\
\text { (code) }\end{array}$ & $\begin{array}{c}\text { Standard } \\
\text { (if applicable) }\end{array}$ & $\begin{array}{l}\text { Testing } \\
\text { time } \\
\text { (h/cycles) }\end{array}$ & Testing conditions & $\begin{array}{c}\text { Test } \\
\text { chambers }\end{array}$ \\
\hline $\begin{array}{l}\text { Continuous neutral salt spray } \\
\text { (NSS) }\end{array}$ & $\begin{array}{c}\text { ISO } \\
9227: 2017\end{array}$ & $120 \mathrm{~h}$ & $\begin{array}{l}{[\mathrm{NaCl}]=50 \pm 5 \mathrm{~g} / \mathrm{L} ;} \\
\mathrm{T}=35 \pm 2{ }^{\circ} \mathrm{C} ; \mathrm{RH}=100 \% ; \\
\mathrm{pH}=6.5-7.2\end{array}$ & $\begin{array}{l}\text { Erichsen } \\
\text { Model } \\
\text { 606/400L }\end{array}$ \\
\hline $\begin{array}{l}\text { Continuous saturated } \\
\text { atmosphere with sulphur } \\
\text { dioxide } \\
\left(\mathbf{S O}_{2}\right)\end{array}$ & $\begin{array}{c}\text { ISO } \\
3231: 1993\end{array}$ & $120 \mathrm{~h}$ & $\begin{array}{l}\text { Each } 24 \mathrm{~h}: 8 \mathrm{~h} 40{ }^{\circ} \mathrm{C} \pm 3{ }^{\circ} \mathrm{C} \\
\text { and } 100 \% \text { of RH }\left(\mathrm{SO}_{2}-\right. \\
0.2 \mathrm{~L}) \text { and } 16 \mathrm{~h} \text { at } 18-28{ }^{\circ} \mathrm{C} \\
\text { and } \mathrm{RH} \text { max } 75 \% \text { (test } \\
\text { chamber vented)) }\end{array}$ & $\begin{array}{l}\text { VLM Model } \\
\text { CCT 400-Air } \\
\text { CTD-A }\end{array}$ \\
\hline $\begin{array}{l}\text { Cyclic exposure to dry and wet } \\
\text { (TDW) }\end{array}$ & NA & $240 \mathrm{~h}$ & $\begin{array}{l}\text { Cycles with } 2 \mathrm{~h} \\
\mathrm{~T}=35 \pm 2{ }^{\circ} \mathrm{C}(\mathrm{RH}>95 \%) \\
+4 \mathrm{~h} \mathrm{~T}=60 \pm 2{ }^{\circ} \mathrm{C} \\
(\mathrm{RH}<30 \%)+2 \mathrm{~h} \\
\mathrm{~T}=50 \pm 2{ }^{\circ} \mathrm{C}(\mathrm{RH}>95 \%)\end{array}$ & $\begin{array}{l}\text { Q-Panel Q- } \\
\text { FOG/CCT600 }\end{array}$ \\
\hline $\begin{array}{c}\text { Cyclic exposure to salt mist, dry } \\
\text { and wet } \\
\text { (NSS + TDW) }\end{array}$ & $\begin{array}{c}\text { ISO } \\
\text { 14993:2001 }\end{array}$ & $240 \mathrm{~h}$ & $\begin{array}{l}\text { Cycles with } 2 \text { h neutral salt } \\
\text { spray (NSS) (ISO } \\
9227: 2017) \\
+4 \mathrm{~h} \mathrm{~T}=60 \pm 2{ }^{\circ} \mathrm{C} \\
(\mathrm{RH}<30 \%)+2 \mathrm{~h} \\
\mathrm{~T}=50 \pm 2{ }^{\circ} \mathrm{C}(\mathrm{RH}>95 \%)\end{array}$ & $\begin{array}{l}\text { Q-Panel Q- } \\
\text { FOG/CCT600 }\end{array}$ \\
\hline $\begin{array}{c}\text { Cyclic variation of corrosion } \\
\text { promoting gases }\left(\mathrm{SO}_{2}+\mathrm{NO}_{2}\right), \\
\text { high humidity, neutral salt spray } \\
\text { and dry } \\
\left(\mathrm{NSS}+\mathbf{S O}_{2}+\mathbf{N O}_{2}+\mathbf{D W}\right) \\
\left(\mathbf{5 h ~ N S S}+\mathbf{S O}_{2}+\mathbf{N O}_{2}+\mathbf{D W}\right) \\
\left(\mathbf{1 8 h} \mathbf{N S S}+\mathbf{S O}_{2}+\mathbf{N O}_{2}+\mathbf{D W}\right)\end{array}$ & $\begin{array}{c}\text { ISO } \\
\text { 21207:2015 }\end{array}$ & $\begin{array}{c}672 \mathrm{~h} \\
\text { (4 cycles) }\end{array}$ & $\begin{array}{l}\text { Each cycle }(1 \text { week): } 2 \mathrm{~h} \\
\text { neutral salt spray }(\mathrm{NSS}) \\
(\text { ISO } 9227: 2017)+22 \mathrm{~h} \\
\text { standard climate }\left(23^{\circ} \mathrm{C} \text { and }\right. \\
50 \% \mathrm{RH})+120 \mathrm{~h} \text { with } \\
\text { corrosive atmosphere } \\
\left(\mathrm{NO}_{2}=1.5 \times 10^{-6}+\right. \\
\left.\mathrm{SO}_{2}=0.5 \times 10^{-6}\right)\left(25^{\circ} \mathrm{C} \text { and }\right. \\
95 \% \mathrm{RH})+24 \mathrm{~h} \text { standard } \\
\text { climate }\left(23^{\circ} \mathrm{C} \text { and } 50 \% \mathrm{RH}\right)\end{array}$ & $\begin{array}{l}\text { Erichsen } \\
\text { Model } \\
\text { 606/400L + } \\
\text { WEISS WK3- } \\
\text { 340/0-BSB }\end{array}$ \\
\hline $\begin{array}{l}\text { Cyclic variation of high } \\
\text { humidity (without gases), } \\
\text { neutral salt spray and dry } \\
\text { (NSS+ DW) }\end{array}$ & NA & $\begin{array}{c}672 \mathrm{~h} \\
\text { (4 cycles) }\end{array}$ & $\begin{array}{l}\text { Each cycle ( } 1 \text { week): } 2 \mathrm{~h} \\
\text { neutral salt spray (NSS) } \\
\text { (ISO } 9227: 2017)+22 \mathrm{~h} \\
\text { standard climate }\left(23^{\circ} \mathrm{C} \text { and }\right. \\
50 \% \mathrm{RH}) 120 \mathrm{~h} \text { at } 25^{\circ} \mathrm{C} \\
\text { and } 95 \% \mathrm{RH} \\
+24 \mathrm{~h} \text { standard climate } \\
\left(23^{\circ} \mathrm{C} \text { and } 50 \% \mathrm{RH}\right)\end{array}$ & $\begin{array}{l}\text { Erichsen } \\
\text { Model } \\
\text { 606/400L + } \\
\text { Fitoclima } \\
\text { S600 }\end{array}$ \\
\hline $\begin{array}{l}\text { Cyclic variation of corrosion } \\
\text { promoting gases }\left(\mathrm{SO}_{2}+\mathrm{NO}_{2}\right) \\
\text { high humidity and dry } \\
\left(\mathbf{S O 2}+\mathbf{N O}_{2}+\mathbf{D W}\right)\end{array}$ & NA & $\begin{array}{c}672 \mathrm{~h} \\
\text { (4 cycles) }\end{array}$ & $\begin{array}{l}\text { Each cycle }(1 \text { week }): 24 \mathrm{~h} \\
\text { standard climate }\left(23^{\circ} \mathrm{C} \text { and }\right. \\
50 \% \mathrm{RH})+120 \mathrm{~h} \text { with } \\
\text { corrosive atmosphere } \\
\left(\mathrm{NO}_{2}=1.5 \times 10^{-6}+\right. \\
\left.\mathrm{SO}_{2}=0.5 \times 10^{-6}\right)\left(25^{\circ} \mathrm{C} \text { and }\right. \\
95 \% \mathrm{RH})+24 \mathrm{~h} \text { standard } \\
\text { climate }\left(23^{\circ} \mathrm{C} \text { and }\right. \\
50 \% \mathrm{RH})\end{array}$ & $\begin{array}{l}\text { WEISS WK3- } \\
\text { 340/0-BSB }\end{array}$ \\
\hline
\end{tabular}




\section{Results and Discussion}

\subsection{Accelerated aging tests}

Photographic records of the samples submitted to neutral salt spray (NSS), continuous saturated atmosphere with sulfur dioxide $\left(\mathrm{SO}_{2}\right)$ and cyclic exposure to temperature, dry and wet without (TDW) and with salt spray (NSS + TDW) are shown in Table 2. Figure 1 shows the results of optical performance (Pc and FM) of these samples during the exposure to the same accelerated aging tests. The red line, that can be seen in the graphs of $P C$, represents the value 0.05 considered by the standard ISO 22975-3:2014 as the higher limit acceptable after aging tests for an absorber coating to be qualified.

When comparing Table 2 with Figure 1, it is clear the direct relationship between corrosion and change in optical performance $(P c)$.

Tab. 2: Photographic records of PVDs (PVD1 and PVD2) and PCs (PC1, PC2 and PC3) after NSS, $\mathrm{SO}_{2}$, TDW and NSS + TDW aging tests

\begin{tabular}{|c|c|c|c|c|}
\hline \multirow{2}{*}{$\begin{array}{c}\text { Absorber } \\
\text { Coating }\end{array}$} & \multicolumn{4}{|c|}{ Aging test (test time) } \\
\hline & NSS (120h) & $\mathrm{SO}_{2}(120 \mathrm{~h})$ & TDW (240 h) & $\begin{array}{c}\text { NSS + TDW } \\
(240 \mathrm{~h})\end{array}$ \\
\hline PVD1 & & & & \\
\hline PVD2 & & & & \\
\hline PC1 & & & & \\
\hline PC2 & & & & \\
\hline PC3 & & & & \\
\hline
\end{tabular}


Neutral salt spray led to a higher degradation in PVDs than in PCs. Considering only PVDs, PVD2 showed higher degradation than PVD1. For PCs, PC3 showed the best behaviour in terms of anticorrosive protection and optical properties (lower $P c$ and higher $F M$ ). For the sulfur dioxide resistance test, opposite results were observed, i.e., the PCs showed higher degradation than PVDs. No significant changes were observed between the two PVDs and the three PCs.

The TDW and NSS tests showed that the PVD2 coating exhibits higher susceptibility than PVD1 to cycles with temperature ( $P C$ and $F M$ ). This fact was also observed, but with less intensity, during the thermal test for coatings qualification according to the standard ISO 22975-3:2014 (Diamantino et al. 2016). Thermal tests according to the standard ISO 22975-3:2014 are performed at higher temperature but without cycles of dry and wet. The opposite occurs with paint coatings (PC1, PC2 and PC3) that maintains or improves FM after TDW testing. In the NSS + TDW test the high susceptibility of PVD coatings in chloride environments is evident again, although this test has lower corrosivity than NSS for aluminum (Figure 4).

In order to better understand the influence of different environmental contaminations, thermal conditioning and drying/wetting on the degradation of these surfaces, five additional accelerated aging tests were carried out $\left(\mathrm{NSS}+\mathrm{SO}_{2}+\mathrm{NO}_{2}+\mathrm{DW}, \quad 5 \mathrm{~h} \quad \mathrm{NSS}+\mathrm{SO}_{2}+\mathrm{NO}_{2}+\mathrm{DW}, \quad 18 \mathrm{~h} \quad \mathrm{NSS}+\mathrm{SO}_{2}+\mathrm{NO}_{2}+\mathrm{DW}, \quad \mathrm{NSS}+\mathrm{DW}\right.$ and $\left.\mathrm{SO}_{2}+\mathrm{NO}_{2}+\mathrm{DW}\right)$.

Before these accelerated aging tests, the influence of thermal conditioning on optical properties of absorber coatings (Figure 2) was also studied. By these results, within PVD coatings only PVD1 shows a slight decrease of $F M$ after thermal conditioning. The paint coatings show a little increase in the $F M$ after $18 \mathrm{~h}$ of thermal conditioning. This tendency also occurred in the TDW test, as well as in the thermal test according to the standard ISO 22975-3:2014 (Diamantino et al. 2016).

Table 3 and Figure 3 show, respectively, the results of the optical properties and visual degradation of the different selective solar absorber surfaces after the exposure to these five accelerated aging tests.

From Figure 3 and table 3, it is also evident the strong effect of chloride on degradation of PVDs and PCs, higher on PVDs. The thermal conditioning does not seem to have a significant effect on the corrosion behaviour and in $P c$ and FM. Only PVD2 presented a higher $P c$ and a lower FM with $18 \mathrm{~h}$ of thermal conditioning, confirming its thermal susceptibility.

The results obtained with the methodology described in the standard ISO 21207:2015 (NSS + $\mathrm{SO}_{2}+\mathrm{NO}_{2}+\mathrm{DW}$ test), considering an accelerated aging test with cyclic variation of corrosion promoting gases $\left(\mathrm{SO}_{2}\right.$ and $\left.\mathrm{NO}_{2}\right)$, higher humidity, salt spraying and drying, are similar to those presented by Diamantino et al. 2017, with the same solar absorber coatings exposed to outdoor exposure testing sites with different corrosivity (urban test site with marine influence - medium corrosivity and an industrial/marine test site with very high /extreme corrosivity) in terms of the ranking of $P c, F M$ and anticorrosive protection.

Another important result was obtained from the data of $P C$ and $F M$ during NSS + DW test, comparatively to $\mathrm{NSS}+\mathrm{SO}_{2}+\mathrm{NO}_{2}+\mathrm{DW}$ test. A worse behaviour of PVDs was observed in NSS + DW than in $\mathrm{NSS}+\mathrm{SO}_{2}+\mathrm{NO}_{2}+\mathrm{DW}$. The only difference between these two aging tests is the presence or absence of corrosive gases (NSS $+\mathrm{SO}_{2}+\mathrm{NO}_{2}+\mathrm{DW}$ with gases and NSS $+\mathrm{DW}$ without gases). It would be expected that the absence of these two corrosive gases would reduce the corrosion, as occurred with paint coatings, and not the reverse as o with PVDs, especially with PVD2. The corrosive gases seems to have some stabilization effect on PVDs degradation. This phenomenon is being investigated. 


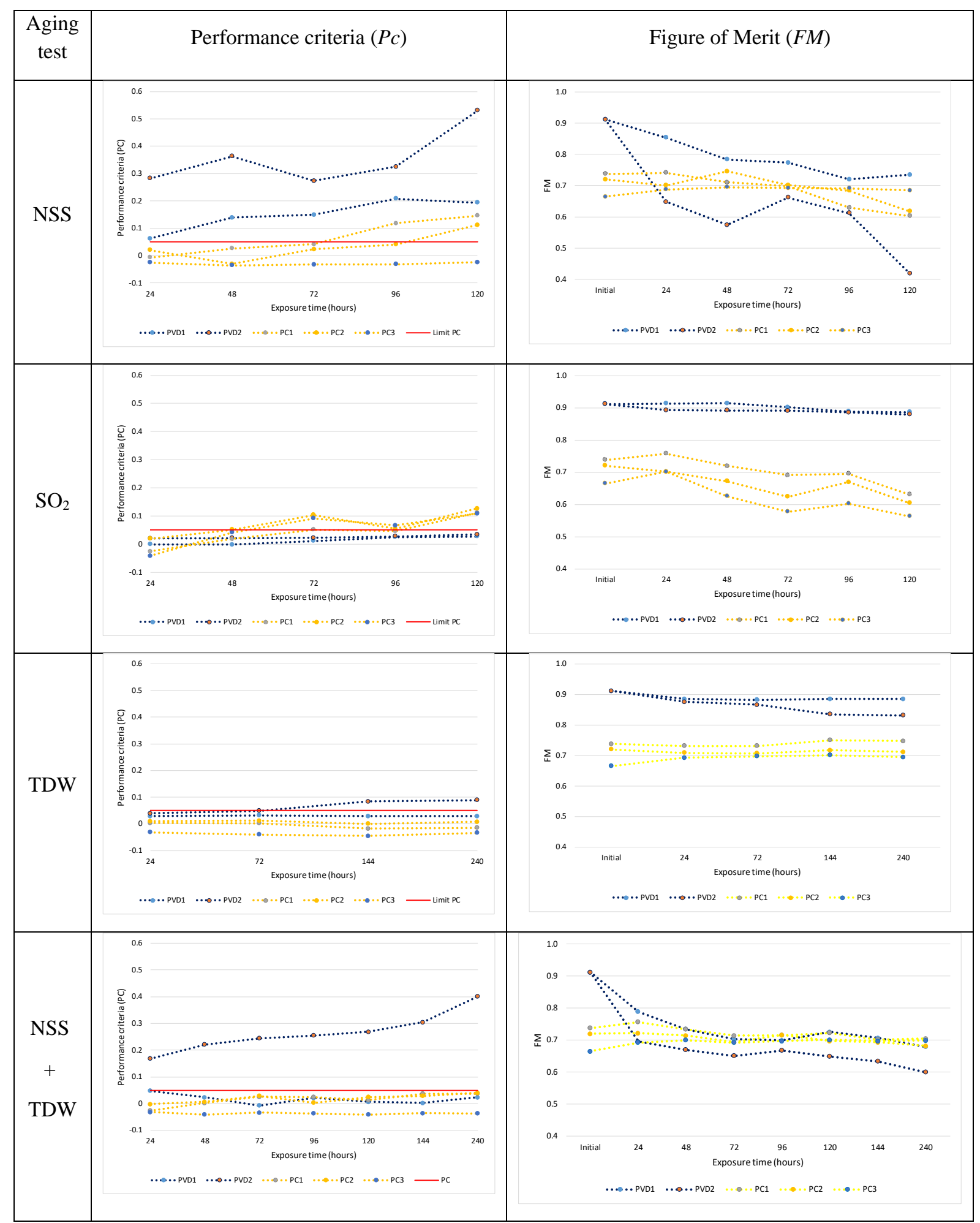

Fig. 1: Evolution of optical properties in terms of Performance Criteria (Pc) and Figure of Merit $(F M)$ of selective solar absorber coatings after NSS, $\mathrm{SO}_{2}$, TDW and NSS + TDW aging tests 


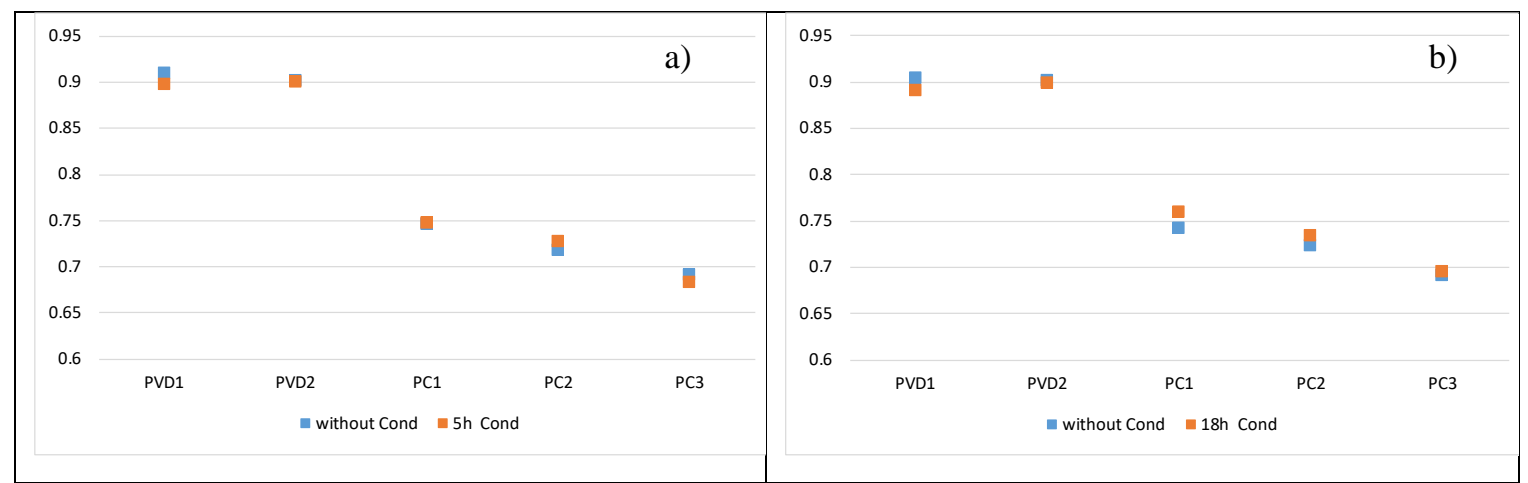

Fig. 2: Figure of Merit (FM) of absorber coatings before and after thermal conditioning during $5 \mathrm{~h}(\mathrm{a}))$ and $18 \mathrm{hours}(\mathrm{b}))$ at $192{ }^{\circ} \mathrm{C}$

Tab. 3: Photographic records of PVDs (PVD1 and PVD2) and PCs (PC1, PC2 and PC3) after NSS $+\mathrm{SO}_{2}+\mathrm{NO}_{2}+\mathrm{DW}, 5 \mathrm{~h}$ $\mathrm{NSS}+\mathrm{SO}_{2}+\mathrm{NO}_{2}+\mathrm{DW}, 18 \mathrm{hSS}+\mathrm{SO}_{2}+\mathrm{NO}_{2}+\mathrm{DW}, \mathrm{NSS}+\mathrm{DW}$ and $\mathrm{SO}_{2}+\mathrm{NO}_{2}+\mathrm{DW}$

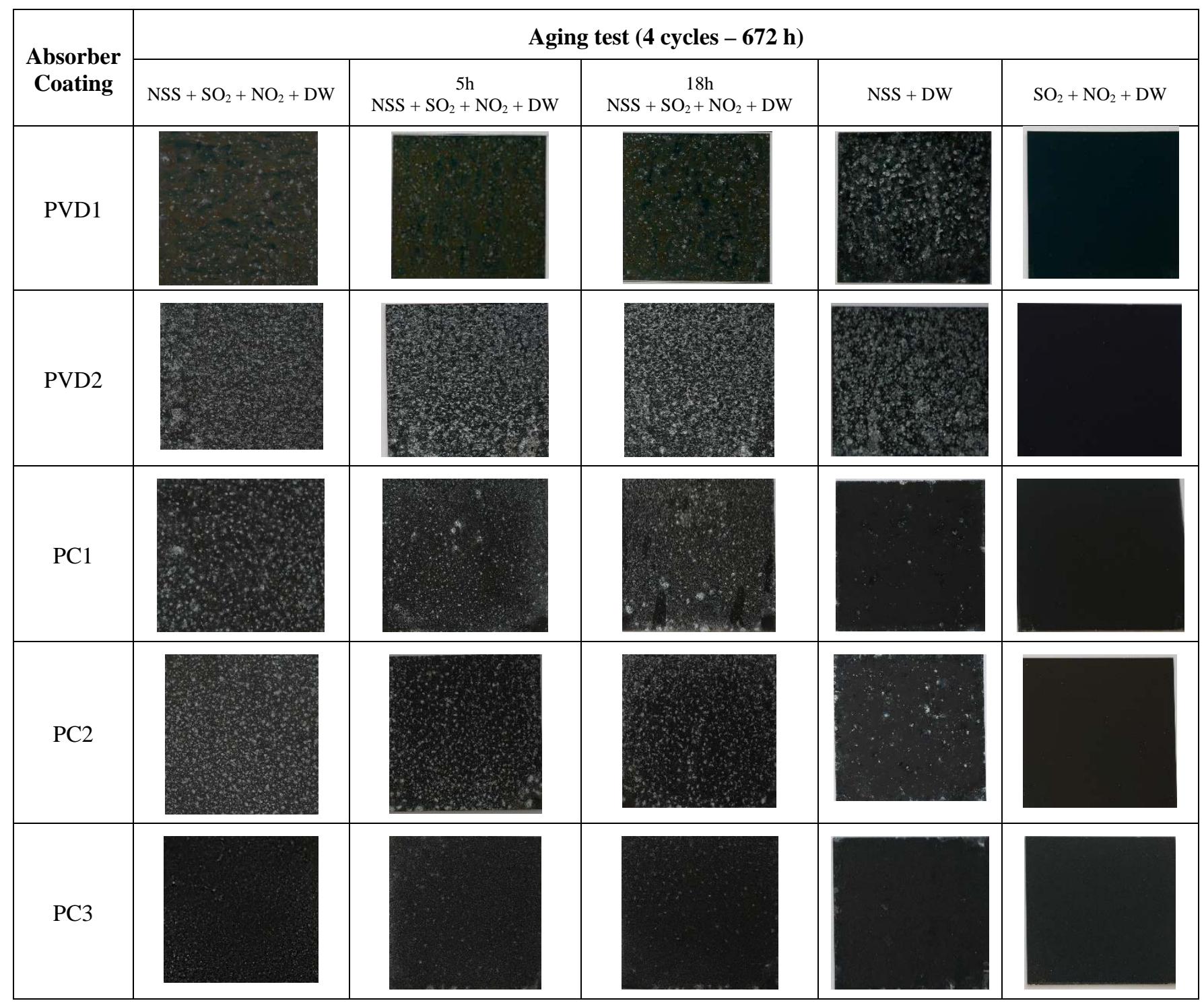




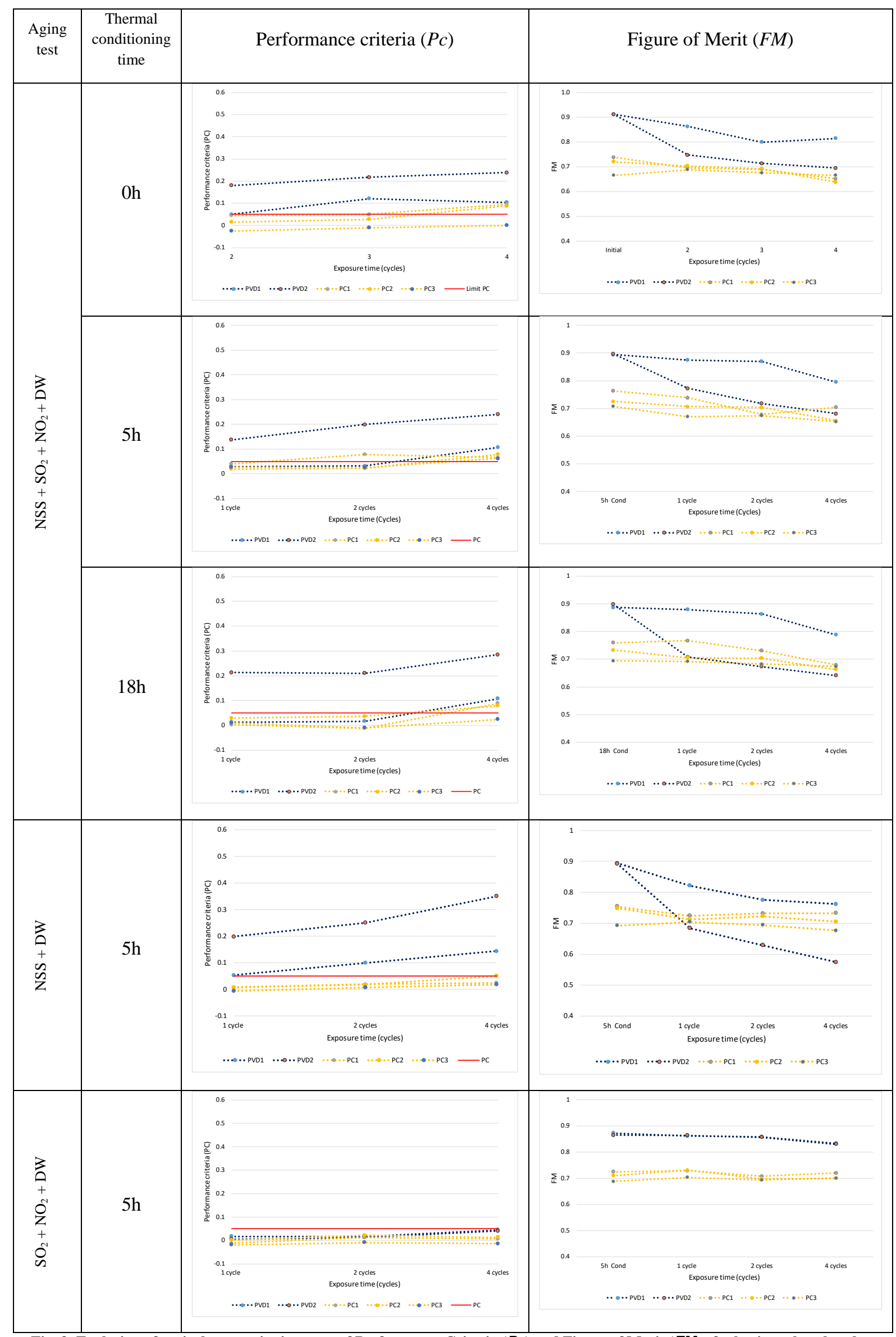

Fig. 3: Evolution of optical properties in terms of Performance Criteria $(P c)$ and Figure of Merit $(F M)$ of selective solar absorber coatings after $\mathrm{NSS}+\mathrm{SO}_{2}+\mathrm{NO}_{2}+\mathrm{DW}, 5 \mathrm{~h} \mathrm{NSS}+\mathrm{SO}_{2}+\mathrm{NO}_{2}+\mathrm{DW}, 18 \mathrm{~h} \mathrm{NSS}+\mathrm{SO}_{2}+\mathrm{NO}_{2}+\mathrm{DW}$ and NSS $+\mathrm{DW}, \mathrm{SO}_{2}+\mathrm{NO}_{2}+\mathrm{DW}^{2}$ aging tests 


\subsection{Corrosivity of accelerated aging tests performed according to ISO standards}

Figure 4 presents the results of the mass loss obtained with four reference materials (steel, aluminum, zinc and copper) after $168 \mathrm{~h}$ of exposure (1 cycle/ 1 week). As can be seen the different materials had different corrosion behaviour depending on the environment. The comparison between the corrosivity of standard aging tests shows that it depends of the material type. For example, aging test performed according with the standard ISO 14993:2001 is a very aggressive test for steel and zinc but not for aluminum and copper. The evaluation of corrosion rate of different aging tests with different reference materials, the same materials and methodologies used during the evaluation of atmosphere corrosivity, gives an important information to understand and correlate the corrosion mechanisms observed in natural outdoor exposure.

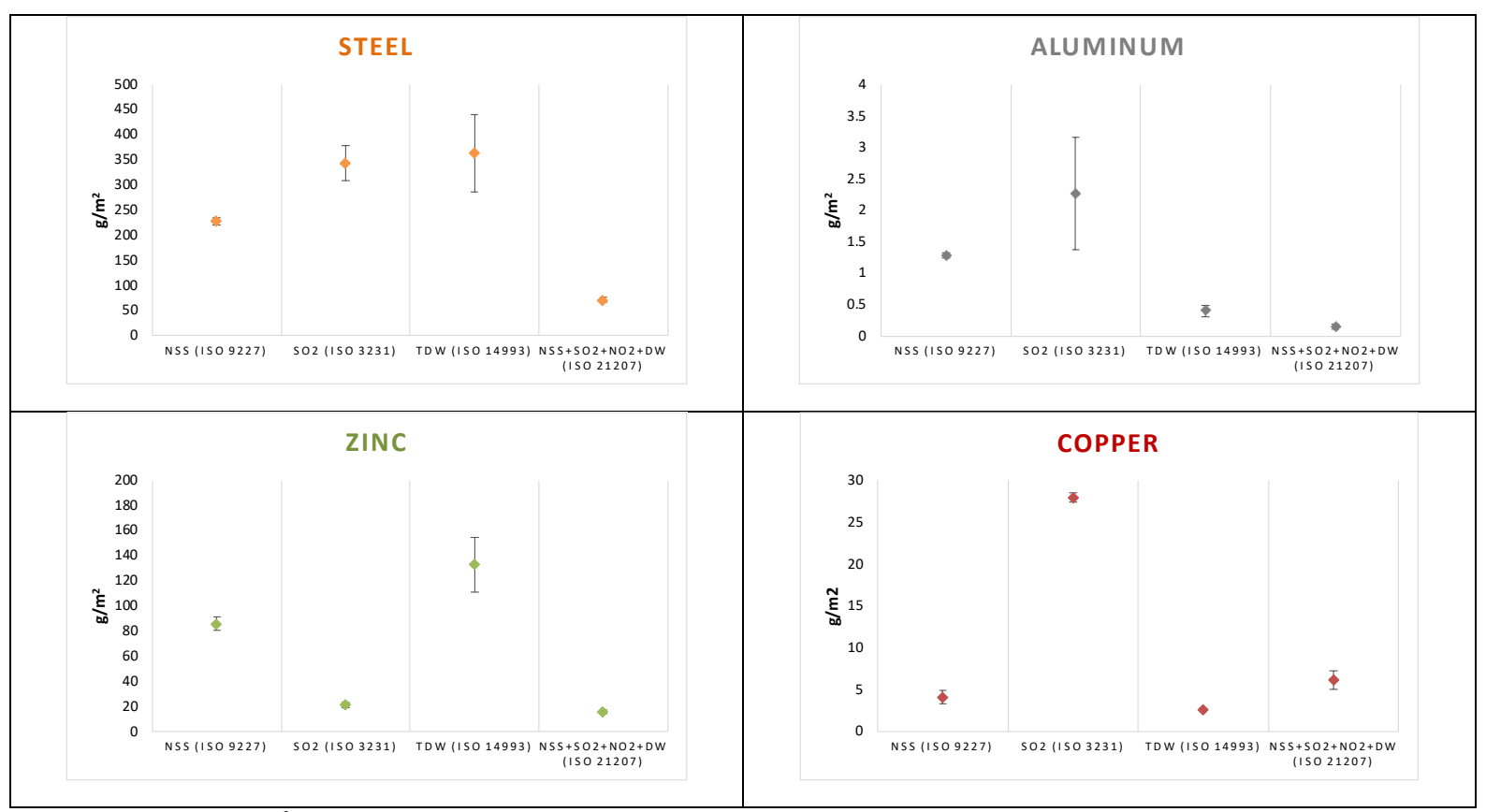

Fig. 4: Mass loss $\left(\mathrm{g} / \mathrm{m}^{2}\right)$ of reference materials (steel, zinc, copper and aluminum) after $168 \mathrm{~h}$ of exposure to standard aging tests

\section{Conclusions}

The main conclusions are:

- Different accelerated aging tests show that PVDs coatings are more susceptible to degradation induced by chlorides (NSS) rather than corrosive gases $\left(\mathrm{SO}_{2}\right)$ and, in some conditions, the presence of corrosive gases $\left(\mathrm{SO}_{2}+\mathrm{NO}_{2}\right)$ seem to provoke a delay in degradation process. In opposite, paint coatings (PC) suffer further degradation with $\mathrm{SO}_{2}$ than with NSS.

- Cyclic variation of corrosion promoting gases $\left(\mathrm{SO}_{2}+\mathrm{NO}_{2}\right)$, higher humidity, salt spraying and drying $\left(\mathrm{NSS}+\mathrm{SO}_{2}+\mathrm{NO}_{2}+\mathrm{DW}\right.$ ) seems to be an aging test that reflects the different environments to which the solar thermal collectors are exposed. In addition to the contaminants ( $\mathrm{NSS}+\mathrm{SO}_{2}+\mathrm{NO}_{2}$ ), drying/wetting cycles (TDW) also play an important role in degradation mechanisms of absorber coatings. Pre-thermal conditioning is also important to be included.

- $\quad$ To define an alternative aging test that guarantee a 25-year service life, additional research is in progress in order to define the influence of the sulfur dioxide and nitrogen oxides in the degradation of absorber coatings.

- It is important to have methodologies to qualify selective absorber coatings as proposed in the standard ISO 22975-3:2014. However, the tests proposed require many hours and do not fully reflect the environments where the collectors are exposed, nor the only test with a corrosive agent $\left(\mathrm{SO}_{2}\right)$ indicated in this standard seems to be suitable. 


\section{Acknowledgments}

The authors would like to thank to the colleagues Ana Soares Vieira and Frederico Ferreira for technical support in the experimental work.

This work is a result of the project FCOMP-01-0124-FEDER-027507 (Ref ${ }^{a}$ FCT RECI/EMS-ENE/0170/2012) supported by Operational Competitiveness Programme (COMPETE) through the European Regional Development Fund (ERDF) and supported by FCT- Fundação para a Ciência e a Tecnologia, I.P. through National Funds and the project POCI-01-0145-FEDER-016709 (Ref ${ }^{a}$ FCT PTDC/EMS-ENE/0578/2014) supported by COMPETE 2020 and LISBOA 2020 under the PORTUGAL 2020 Partnership Agreement through the European Regional Development Fund (ERDF) and supported by FCT through National Funds.

\section{References}

Carlsson B., Möller K., Köhl M., Heck M., Brunold S., Frei U., Marechal J.-C., Jorgensen G.. The applicability of accelerated life testing for assessment of service life of solar thermal components, Sol. Energ. Mat. Sol. C. 84 (2004) 255-274 http://dx.doi.org/10.1016/j.solmat.2004.01.046

Carvalho M.J., Páscoa S., Mexa N., Gonçalves R., Correia J., Gano A., Diamantino T.. Solar thermal collector’s degradation - Influence of corrosivity inside and outside the collectors. SHC Conference. Abu Dhabi, $20^{\text {th }}$ October- 2nd November, 2017

Diamantino, T. C., Gonçalves R., Nunes A., Páscoa S., Carvalho M. J.. Durability of different selective solar absorber coatings in environments with different corrosivity. Sol. Energ. Mat. Sol. C., (2017) 166, 27-38 https://doi.org/10.1016/j.solmat.2017.03.004

Diamantino T. C., Nunes A., Gonçalves R., Páscoa S., Chambino T. and Carvalho M. J.. Selective Absorber Coatings Qualification - ISO 22975-3:2014 Full Application EuroSun 2016 / ISES Conference Proceedings (2016), Palma, 11-14 October, 2016

D.E. Roberts, A figure of merit for selective absorbers in flat plate solar water heaters, Solar Energy 98 (2013) 503-510 http://dx.doi.org/10.1016/j.solener.2013.10.012

Slamova K., Duerr I., Kaltenbach T., Koehl M.. Degradation effects of maritime atmosphere on metallic components of solar collectors, Sol. Energ. Mat. Sol. C. 147 (2016) 246-254 http://dx.doi.org/10.1016/j.solmat.2015.12.011 
